\title{
Development of Rat Model with Iron Deficiency Anemia by Modification of Its Standard Food
}

\author{
Susanti, Tri ${ }^{1}$ \\ Postgraduate Program of Nutrition Science \\ Universitas Sebelas Maret \\ Nutritionist in Gondangrejo Community Health Center \\ Surakarta, Indonesia \\ xanti81@gmail.com \\ Indarto, Dono ${ }^{3}$ \\ Department of Physiology, Faculty of Medicine \\ Universitas Sebelas Maret \\ Surakarta, Indonesia \\ DonoIDN323@gmail.com
}

\author{
Dirgahayu, Paramasari ${ }^{2}$ \\ Department of Parasitology, Faculty of Medicine \\ Universitas Sebelas Maret \\ Surakarta, Indonesia \\ Paramasari123@gmail.com
}

\begin{abstract}
Anemia is a nutritional problem in the world which is mainly caused iron deficiency and its global prevalence reaches $\mathbf{2 9 - 4 3 \%}$. Animal models with iron deficiency anemia (IDA) have been generated in some research centers but they used different standard diets and need longer time. Therefore the aim of this study was to investigate reduction of hemoglobin $(\mathrm{Hb})$ levels in rat model with IDA. This study used 24 female Wistar rats which aged 2 months old and had $\pm 200 \mathrm{~g}$ body weight and $\mathrm{Hb}$ levels $>13$ g/dl in the Laboratory of Food and Nutrition Study Center, Gadjah Mada University for 22 days. Each group consisted of 6 rats and control group (C) got AIN 93M standard food for 15 days. While treatment groups (T) got low iron diet of AIN 93M food for 5 (T1), 10 (T2) and 15 (T3) days. Hb levels were measured using the cyanmethemoglobin method. All collected data were analyzed using independent and paired t-student, Anova followed by Tukey post hoc and Mann Whitney tests with $p$ value $<0.05$. $T$ groups significantly had lower $\mathrm{Hb}$ levels than the control group $(\mathrm{p}<0.001)$. The lowest $\mathrm{Hb}$ levels $(8,5 \pm 0,4 \mathrm{~g} / \mathrm{dl})$ were observed in T3 group. The mean different of $\mathrm{Hb}$ levels in T3 group $(5,7 \pm 0,2 \mathrm{~g} / \mathrm{dl})$ was significantly higher than in $\mathrm{T} 1$ and $\mathrm{T} 2$ groups. Administration of low iron diet of food standard decreases rat $\mathrm{Hb}$ levels less than $10 \mathrm{~g} / \mathrm{dl}$ in 10 or 15 days.
\end{abstract}

\section{Keywords - Rats model; iron deficiency anemia; hemoglobin levels}

\section{INTRODUCTION}

Anemia is a worldwide nutritional problem with $29-43 \%$ the global prevalence $[1,2]$. Children, pregnant women and nonpregnant women are more susceptible to suffer iron deficiency than other age groups [3] due to increased physiological needs of iron during growth period and pregnancy or increased iron loss during menstruation [2]. Forty three percent population in developing countries have anemia, which it is $47 \%$, in infants, $42 \%$ in pregnant women, and $30 \%$ in non-pregnant women (15-49 years old) [4]. If iron intake is not sufficient enough, iron deficiency will continue and deplete iron storage from liver and spleen, resulting in iron deficiency anemia (IDA) [5].

Food fortification and iron supplementation are nationally conducted to reduce IDA in Indonesia. Although the coverage of iron supplementation in pregnant women is high but the prevalence of anemia remains high [6]. The main cause of high prevalence of anemia has not been established yet. In order to unravel the pathogenesis of IDA, animal models are highly required. However, a few experimental animals or animal models of anemia are not well characterized [7,8].

The Wistar rat (Rattus norvegicus) is mostly used as experimental animals in biomedical research because it physiologically has high similarities with human body [9]. Fatimah (2009) has generated anemic rat model by withdrawing $20 \%$ caudal venous blood but this rat model is not represented IDA [10,11]. Zhu, et al. (2016) and Xiao, et al. (2016) studies generated rat model of anemia with a low-iron diet for eight or three weeks which $\mathrm{Hb}$ levels reduced to $11.9 \pm$ $1.5 \mathrm{~g} / \mathrm{dl}$ or $\leq 10 \mathrm{~g} / \mathrm{dl}$ respectively [12,13]. While Yun et al. (2011) developed the same model with low-iron diet of AIN 76A standard food just for four weeks with $\mathrm{Hb}$ level $\leq 10 \mathrm{~g} / \mathrm{dl}$ [14]. Unfortunately, the AIN 76A standard food is no longer produced. Therefore we developed anemic rat model with low iron diet of AIN 93M in three different times (5, 10 and 15 days).

\section{METHODS}

A randomized control trial with pre-posttests control group design was used in this study. Twenty four female Wistar rats (Rattus norvegicus) were selected as research samples which met the criteria: aged 2 months old, had $\pm 200 \mathrm{~g}$ body weight and $\mathrm{Hb}$ levels $>13 \mathrm{~g} / \mathrm{dl}$. This experimental study was commenced with seven days adaptation and 15 days intervention. It was conducted in the Laboratory of Food and Nutrition Study Center, Gadjah Mada University. All selected rats were randomly divided into 4 groups: control group (C) administered with purified diet American Institute of Nutrition Mature formula (AIN 93M) standard food, treatment groups T1 (5 days), T2 (10 days) and T3 (15 days) were administered with low iron diet of AIN 93M standard food. The research protocol of this study was approved by Health Research Ethics Committee Dr. Moewardi General Hospital/Faculty of 
Medicine, Universitas Sebelas Maret, Surakarta number 784/VIII/HREC/2017.

\section{A. Generating Rat Model with IDA}

Female Wistar rats were maintained in a stainless cage with $12 \times 15 \times 25 \mathrm{~cm}$ in size for 7 days. Daily temperature was manually controlled and maintained at $18-27^{\circ} \mathrm{C}$ with $40-70 \%$ humidity and 12 hours light-dark [15]. Rats in the $\mathrm{C}$ group were administered with $10 \%$ of their total body weight of AIN $93 \mathrm{M}$ dry palette which contained $37 \mathrm{mg}$ iron/1,000g. While treated groups were administered with the same amount of AIN 93M dry palette which no iron derived from mineral mix. Rats in the T1, T2 and T3 groups was sacrificed after 5, 10 and 15 days treatment respectively while rats in the $\mathrm{C}$ group were sacrificed in the day as same as the T3 group. Rats freely accessed water during the treatment [16] and were given once daily AIN 93M standard foods which were weighed using an analytical weighing with $110 \mathrm{~g}$ capacity. Body weight was regularly measured every 5 days using Camry digital weighing with $7 \mathrm{~kg}$ capacity.

\section{B. Hb Level Measurement}

A total of $0.5 \mathrm{ml}$ whole blood was drawn from orbital vein of each rat in all groups. The blood was collected into a sterile tube with Ethylene diaminetetra acetic acid (EDTA) anticoagulant. Rats were then sacrificed using ether solution. $\mathrm{Hb}$ levels were measured using the cyanmethemoglobin method.

\section{Statistical Analysis}

All collected data were analyzed using independent and paired t-tests to distinguish body weight and $\mathrm{Hb}$ level between $\mathrm{C}$ and $\mathrm{T}$ groups. The Anova test followed by Tukey post hoc was used to analyze the different effect of low iron diet in 5, 10 and 15 days treatment in $\mathrm{C}$ and $\mathrm{T}$ groups. Delta body weight and $\mathrm{Hb}$ levels in both groups were analyzed using Mann Whitney and Anova tests respectively. Significant values were set up $<0.05$.

\section{RESULTS}

\section{A. Body Weight}

The effect of low iron diet on rat body weight was evaluated in this study. Fig. 1 showed that low iron diet did not influence rat body weight in all treated groups. Before treatment, rats in $\mathrm{C}, \mathrm{T} 1$ and $\mathrm{T} 2$ groups had similar averages of body weight $(184.8 \pm 4.6,184.0 \pm 4.6,183.2 \pm 4.7 \mathrm{~g})$ while T3 group had higher average of body weight compared with the earlier groups $(189.0 \pm 6.5 \mathrm{~g})$. In the day five, higher average of body weight was observed in C and T3 groups (193.2 \pm 4.9 and $194.5 \pm 6.0 \mathrm{~g})$ than that of in T1 and T2 groups $(189.2 \pm 4.4$ and $188.0 \pm 3.7 \mathrm{~g}$ ) but the different body weight was not statistically significant $(\mathrm{p}>0.05$ ). During 10 and 15 days treatment, T3 treated rats had lower average of body weight than $\mathrm{C}$ rats but it did not reach significance. In addition, rats in T2 group had significantly lower average of body weight compared with $\mathrm{C}$ group $(193.2 \pm 3.8$ vs., $200.7 \pm 5.0 \mathrm{~g})$ with $\mathrm{p}$ $=0.05$.

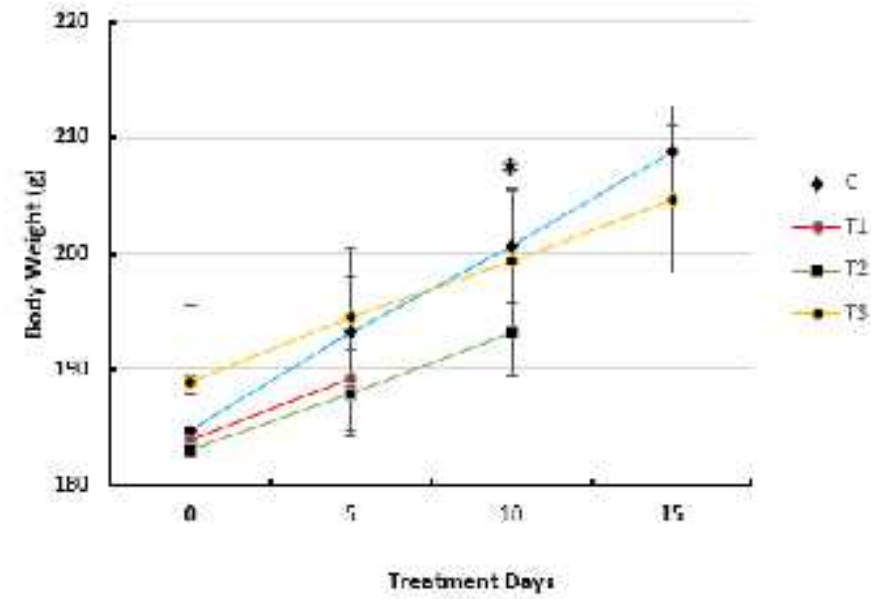

Fig. 1 Average of body weight in $\mathrm{C}$ and $\mathrm{T}$ rat groups after 5, 10 or 15 days of low iron treatment. Each rat group consisted of 6 rats and data were presented in mean $\pm \mathrm{SD}$. * designated significant different compared with C group.

From Table 1, it showed that all treated rats groups had lower averages of $\Delta$ body weight compared with $\mathrm{C}$ group after low iron treatment. The highest average of $\Delta$ body weight was in C group $(24.0 \pm 1.4 \mathrm{~g})$ and followed by T3 (15.9 \pm 0.5$)$ and $\mathrm{T} 2$ groups $(10.0 \pm 1.1 \mathrm{~g})$. Whereas rats in T1 group had the smallest average of $\Delta$ body weight $(5.2 \pm 1.2 \mathrm{~g})$. Significant differences of $\Delta$ body weight were found in either $\mathrm{C}$ or $\mathrm{T}$ groups before and after low iron treatment $(\mathrm{p}=0.003$ and $\mathrm{P}<$ 0.01 ). Surprisingly, $\Delta$ body weight in T2 and T3 groups increased two and three folds than $\Delta$ body weight in $\mathrm{T} 1$.

TABLE I

DIFFERENT AVERAGES OF BODY WEIGHT IN C AND T RAT GROUPS

\begin{tabular}{|l|c|c|c|c|}
\hline \multirow{2}{*}{ Group } & \multicolumn{4}{|c|}{ Averages of $\Delta$ Body Weight (g) } \\
\cline { 2 - 5 } & $\begin{array}{c}\text { Before } \\
\text { Treatment }\end{array}$ & $\begin{array}{c}\text { After } \\
\text { Treatment }\end{array}$ & $\begin{array}{c}\Delta \text { Body } \\
\text { Weight }\end{array}$ & p \\
\hline C & $184.8 \pm 4.6$ & $208.8 \pm 4.0$ & $24.0 \pm 1.4$ & 0.003 \\
\hline T1 & $184.0 \pm 4.6$ & $189.2 \pm 4,5$ & $5.2 \pm 1.2$ & \\
\hline T2 & $183.2 \pm 4.7$ & $193.2 \pm 4.8$ & $10.0 \pm 1.1$ & \\
\hline T3 & $189.0 \pm$ & $204,7 \pm 6,3$ & $15.9 \pm$ & \\
& 6.5 & & 0.5 & \\
\hline
\end{tabular}

\section{B. Haemoglobin Level}

As can be seen from Fig. 2, it indicated that administration of low iron in the standard food reduced $\mathrm{Hb}$ levels in day dependent manner. The averages of $\mathrm{Hb}$ levels in all $\mathrm{T}$ rat groups were significantly lower than the average of $\mathrm{Hb}$ levels in the $\mathrm{C}$ rat group $(\mathrm{p}=0.003)$. Rats in $\mathrm{T} 3$ group had the lowest average of Hb levels $(8.5 \pm 0.4 \mathrm{~g} / \mathrm{dl})$ and followed by T2 $(9.7 \pm$ $0.2 \mathrm{~g} / \mathrm{dl})$ and $\mathrm{T} 1(11.8 \pm 0.4 \mathrm{~g} / \mathrm{dl})$ groups. The average of $\mathrm{Hb}$ levels in T3 group were statistically different from the average of $\mathrm{Hb}$ levels in $\mathrm{T} 2$ and $\mathrm{T} 1$ groups ( $\mathrm{p}<0.001)$. In addition, a significant difference of $\mathrm{Hb}$ levels was found in $\mathrm{T} 2$ rat group versus T1 rat group with $\mathrm{p}<0.001$. 


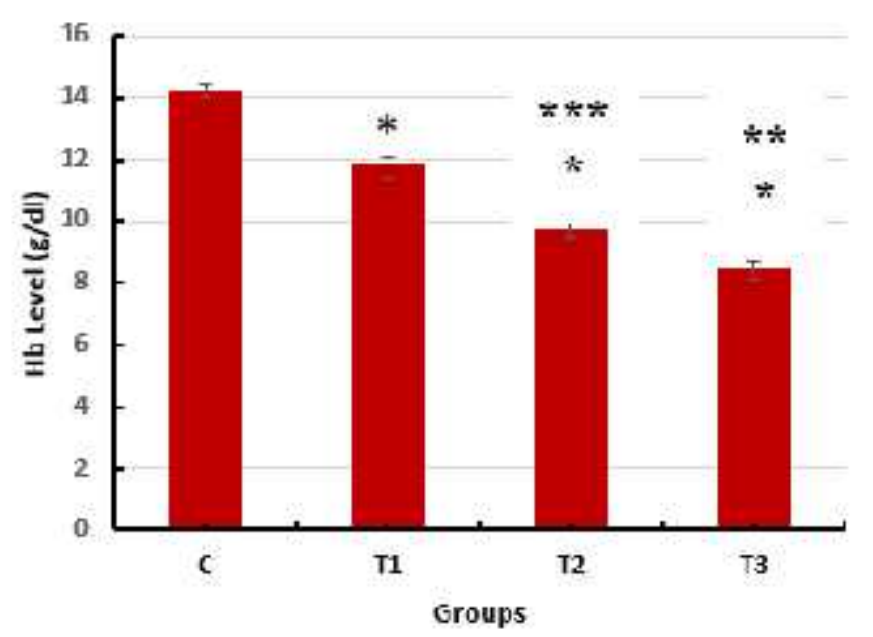

Fig. 2. Average of $\mathrm{Hb}$ levels in $\mathrm{C}$ and $\mathrm{T}$ rat groups after 5, 10 or 15 days of low iron treatment. Each rat group consisted of 6 rats and data were presented in mean $\pm \mathrm{SD}$. *designated significant different compared with $\mathrm{C}$ group, ** was comparison between $\mathrm{T} 1$ and $\mathrm{T} 2 / \mathrm{T} 3$ groups and $* * *$ was $\mathrm{T} 2$ compared with $\mathrm{T} 3$ rat groups.

Table 2 showed that all $\mathrm{T}$ groups had higher different average of $\mathrm{Hb}$ levels compared with different average of $\mathrm{Hb}$ levels in $\mathrm{C}$ group after low iron treatment. The highest average of $\Delta \mathrm{Hb}$ levels was in $\mathrm{T} 3$ group $(-5.7 \pm 0.2 \mathrm{~g} / \mathrm{dl})$ and followed by $\mathrm{T} 2(-4.6 \pm 0.1 \mathrm{~g} / \mathrm{dl})$ and $\mathrm{T} 1(-2.4 \pm 0.1 \mathrm{~g} / \mathrm{dl})$ groups. Average of $\Delta \mathrm{Hb}$ levels in all treated groups significantly differed from the average of $\Delta \mathrm{Hb}$ levels in $\mathrm{C}$ group $(\mathrm{p}<0.001)$. The average of $\Delta \mathrm{Hb}$ levels in $\mathrm{T} 2$ and $\mathrm{T} 3$ groups was statistically different from the average of $\Delta \mathrm{Hb}$ levels in T1 group ( $\mathrm{p}<0.001)$. Moreover, a significant difference of $\Delta \mathrm{Hb}$ levels was found in T2 group compared with T3 group with $\mathrm{p}<0.001$.

TABLE 2

DIFFERENT AVERAGES OF HB LEVELS IN C AND T RAT GROUPS

\begin{tabular}{|l|c|c|c|c|}
\hline \multirow{2}{*}{ Group } & \multicolumn{4}{|c|}{ Averages of Hb Level (g/dl) } \\
\cline { 2 - 5 } & $\begin{array}{c}\text { Before } \\
\text { Treatment }\end{array}$ & $\begin{array}{c}\text { After } \\
\text { Treatment }\end{array}$ & $\begin{array}{c}\mathbf{\Delta ~ H b} \\
\text { Level }\end{array}$ & p \\
\hline C & $14.2 \pm 0.2$ & $14.2 \pm 0.2$ & $-0.0 \pm 0.1$ & 1.000 \\
\hline T1 & $14.2 \pm 0.3$ & $11.8 \pm 0.4$ & $-2.4 \pm 0.1$ & $<0.001$ \\
\hline T2 & $14.3 \pm 0.2$ & $09.7 \pm 0.2$ & $-4.6 \pm 0.1$ & $<0.001$ \\
\hline T3 & $14.2 \pm 0.2$ & $08.5 \pm 0.4$ & $-5.7 \pm 0.2$ & $<0.001$ \\
\hline
\end{tabular}

\section{DISCUSSION}

In this present study, we have demonstrated that AIN 93M standard diet containing mineral mixture without iron was able to decrease rat growth and $\mathrm{Hb}$ levels $<10 \mathrm{~g} / \mathrm{dl}$ after 10 or 15 days treatment. Decreased rat body weight in our study was in line with Tanaka's study. Rats were treated with $3.6 \mathrm{ppm}$ iron citrate decreased $13.6 \%$ their body weights after 6 weeks treatment, compared with body weight in the control group [17]. However, low iron diet in our study just decreased $3.7 \%$ and $1.9 \%$ rat body weight after 10 and 15 days treatment respectively. The different result of these studies is due to the amount of daily diet intake. We fed around $20 \mathrm{~g} /$ day standard diet in all control and treated rats until the end of the study but Tanaka and co-worker fed their experimental rats with a standard diet depending on weekly rat consumption. Therefore, growth retardation in our study may result from iron-deficient diet instead of malnutrition.

After 10 to 15 days, mean $\mathrm{Hb}$ levels in our study reduced < $10 \mathrm{~g} / \mathrm{dl}$ which was comparable with others studies in longer time periods. Zhu et al. (2016) used their own standard diet containing mineral mixture without iron to induce anemia in their experimental rats for 8 weeks. In the end of their study, mean $\mathrm{Hb}$ levels reduced from $17.7 \pm 0.8 \mathrm{~g} / \mathrm{dl}$ to $11.9 \pm 1.5 \mathrm{~g} / \mathrm{dl}$, which was as same Hb levels as the result in our study [12]. Moreover, anemic rat model was developed by Xiao et al. (2016). The experimental rats were given a standard diet with 8 $\mathrm{mg} \mathrm{Fe} / \mathrm{kg}$ for 21 days and mean Hb levels $<10 \mathrm{~g} / \mathrm{dl}$. So our method generating rat model with IDA is better than other previous methods [13].

Although we have successfully developed rat model with IDA, there are some limitations in this study. Firstly, we did not measure erythrocyte amount and hematocrit levels to calculate MCV (Mean Corpuscular Volume), MCH (Mean Corpuscular Hemoglobin) and MCHC (Mean Corpuscular Hemoglobin Concentration) which are important indicators for description of microcytic hypochromic erythrocyte in IDA. Secondly, iron levels in blood circulation, transferrin-bound iron and iron storage (ferritin) are not measured in this study. Therefore, we do not know the chronology of iron deficiency anemia in our rat model.

\section{CONCLUSIONS}

Rat model with IDA can be established by iron depletion of mineral mixture in the AIN 93M standard diet in 10 or 15 days. Further investigation such as erythrocyte indexes, serum iron level, transferrin saturation and serum ferritin level are required to confirm our rat model with IDA.

\section{ACKNOWLEDGMENTS}

We would like to thank all staff in the Laboratory of Food and Nutrition Study Center, Gadjah Mada University, Yogyakarta for maintaining rats during in this study and testing $\mathrm{Hb}$ levels. We also appreciate to the Universitas Sebelas Maret which provides a research grant to support this study.

\section{REFERENCES}

[1] World Health Organization. (2011). The global prevalence of anaemia in 2011. [Online]. Available: www.who.int > nutrtition > micronutrients,

[2] World Health Organization. (2014). Global nutrition targets 2025: Anaemia policy brief. [Online]. Available: www.who.int > golbaltarget-2025.

[3] A. Lopez, P. Cacoub, I. C. Macdougall, and L. Peyrin-Biroulet, "Iron deficiency anaemia," The Lancet, vol. 387, pp. 907-916, Peb. 2016.

[4] E. Mc Lean, M. Cogswell, L. Egli, D. Wojdyla, and B. de Benoist. "Worldwide prevalence of anaemia, WHO vitamin and mineral nutrition information system, 1993-2005," Public Health Nutritition, vol. 12, pp.444-454, Apr. 2009.

[5] A. Amalia and A. Tjiptaningrum, "Diagnosis dan tatalaksana anemia defisiensi besi," Majority. vol. 5, pp. 166-169, Dec. 2016. 
[6] Kemenkes, RI. (2014). Peraturan Menteri Kesehatan RI no. 88 tahun 2014 tentang standart tablet tambah darah bagi wanita usia subur dan ibu hamil.

[Online].

Available: http://sinforeg.litbang.depkes.go.id/upload/regulasi/PMK_No. $88 \quad$ ttg Tabet Tambah Darah pdf. 2014.

[7] J. L. Ihedioha, J. I. Ugwuja, O. A. Noel-Uneke, I. J. Udeani and G. Daniel-Igwe, "Reference values for the haematology profile of conventional grade outbred albino mice (Mus musculus) in Nsukka, Eastern Nigeria," Anim Res Int., vol. 9, pp. 1601-1612, 2016.

[8] L. Fitria and M. Sarto, "Profil hematologi tikus (Rattus norvegicus berkenhout, 1769) galur wistar jantan dan betina umur 4, 6, dan 8 minggu," Biogenesis, vol. 2, pp. 94-100, Dec 2014.

[9] J. B. Smith and S. Mangkoewidjojo. Pemeliharaan, pembiakan dan penggunaan hewan percobaan di daerah tropis. Canberra, Australia: International Development Program of Australian Universities and Colleges, 1987.

[10] Fatimah, "Studi kadar klorofil dan zat besi (Fe) pada beberapa jenis bayam terhadap jumlah eritrosit tikus putih (Rattus Norvegicus) anemia," S.Si. mini thesis, University of Islam Negeri Maulana Malik Ibrahim, Malang, July 2009.

[11] Z. Zuhrawati, N. Asmilia, A. Rizky, Z. Zuraidawati, N. Nazaruddin, and M. Adam, "Pengaruh pemberian infusa daun labu siam (Sechium edule) terhadap kadar hemoglobin dan nilai hematokrit tikus putih (Rattus norvegicus) anemia," Jurnal Medika Veterinaria, vol. 9, pp. 80-84, Agust. 2015.

[12] Q. Zhu, Y. Qian, Y. Yang, W. Wu, J. Xie, and D. Wei. "Effects of carbonyl iron powder on iron deficiency anemia and its subchronic toxicity," J. Food Drug Anal., vol. 24, pp. 746-53, June 2016.

[13] C. Xiao, X. Lei, Q. Wang, Z. Du, L. Jiang, and S. Chen, "Effects of a tripeptide iron on iron-deficiency anemia in rats," Biol. Trace Elem. Res., vol. 169 , pp. 211-217, Feb. 2016
[14] S. Yun, T. Zhang, M. Li, B. Chen, G. Zhao, "Proanthocyanidins inhibit iron absorption from soybean (glycine max) seed ferritin in rats with iron deficiency anemia." Plant Foods Hum. Nutr. vol. 66, pp. 212-217, Sep. 2011.

[15] D. Kusumawati, Bersahabatlah dengan Hewan Coba, Ed. Yogyakarta: Gadjah Mada University Press, 2004.

[16] W. Widiartini, E. Siswati, A. Setiyawati, I. M. Rohmah, E. Prastyo. "Pengembangan usaha produksi tikus putih (Rattus norvegicus) tersertifikas dalam upaya memenuhi kebutuhan hewan laboratorium," in e-proceedings Program Kreativitas Mahasiswa-Kewirausahaan, Dec. 29, 2013.

[17] M. Tanaka, MT. Kusuda, K. Abe, and M. Nagasaka, "Effects of iron deficiency anemia on growth rate of rats," Jstage, vol. 3, pp. 67-75. 2009. 